\title{
AIRBORNE BIO-PARTICULATE OBJECTS AT CHITTAGONG UNIVERSITY CAMPUS
}

\author{
MK PASHA* AND MOHAMmad SOHRAB HoSSAIN ${ }^{1}$ \\ Department of Botany, University of Chittagong, Chittagong-4331, Bangladesh
}

Key words: Airborne particulate objects, Plant parts, Insect appendages, Chittagong University Campus

\begin{abstract}
Survey of airborne bio-particulate objects was carried out at Chittagong University Campus during October, 2006 to September, 2007. A total of 1,451 such airborne objects were encountered consisting of plant parts and non-plant parts. Flower parts made the highest contribution, followed by dermal appendages, filamentous objects, fungal spores, plant tissues and insect appendages. Maximum concentration of airborne bio-particulate objects were observed in the month of June and minimum in November.
\end{abstract}

Some microscopic plant parts/fragments, other than pollen and spores, are frequently present in the air as organic pollutants. Ramalingam (1971) reported $10.60 \%$ of such plant parts among other objects in the air of Mysore in India. Tilak (1974) also observed the presence of epidermal hairs of plant origin from the atmosphere of Aurangabad. Airborne plant parts are also responsible for plant diseases as Tilak and Chakre (1977) reported the seasonal variations and incidence of diseases of cereal grains in storage caused by airborne bio-pollutants. Besides, airborne plant parts are suspected to be the causal agents of upper respiratory tract and naso-bronchial allergy including asthma, hay fever together with several eye, skin and respiratory disorders (D'Amato et al. 1994).

The early attempts related to aerobiology included aeropalynological research work in Bangladesh, from Chittagong were by Badya and Pasha (1991) and Pasha and Hossain (2009). This is the first attempt to trap and identify the airborne bio-particulate objects other than spore in the Chittagong University Campus ( $22^{\circ} 24^{\prime \prime} \mathrm{N}$ and $\left.91^{\circ} 50^{\prime \prime} \mathrm{E}\right)$. This airborne bio-particulate matters survey was carried out by using Gregory's sampler method (Gregory 1961). This sampler is grouped under the impaction type using wind movement by vertical and inclined microscope slide. From October, 2006 to September, 2007 two slides, smeared with glycerine jelly were placed in sampler at $10 \mathrm{~m}$ height roof from the ground level. With an interval of every 24 hours, the slides were collected from the trap and covered with $18 \times 18 \mathrm{~mm}$ cover glass. The covered areas were examined under microscope instantly or within a few days afterwards.

Multicellular spores and pseudo-septate hyphae like fungal structures were found (Figs 1-2) along with algal filaments (Fig. 3), flower parts (sterile glumes, bracts, Figs 5 and 6) of poaceous plants and pappus of asteraceous plants, etc. Dermal appendages including trichomes of plant organs, etc. (Figs 7-8). Plant tissues are both parenchymatous and sclerenchymatous in nature (Fig. 9). Trapped insect legs and wings collectively grouped into insect appendages (Figs 10, 11 and 12) were also found.

A total of 1,451 airborne bio-particulate objects were observed and classified into plant parts and non-plant parts (Table 1). Among the identified particulate objects, flower parts showed the highest frequency, followed by dermal appendages, filamentous objects (algae), plant tissues and insect appendages. The unidentified airborne particulate objects (spores) contributed 29.08\% (Table 1).

*Corresponding author: <pashamk49@yahoo.com>. 'Gachhbaria Govt. College, Chandanaish, Chittagong, Bangladesh. 

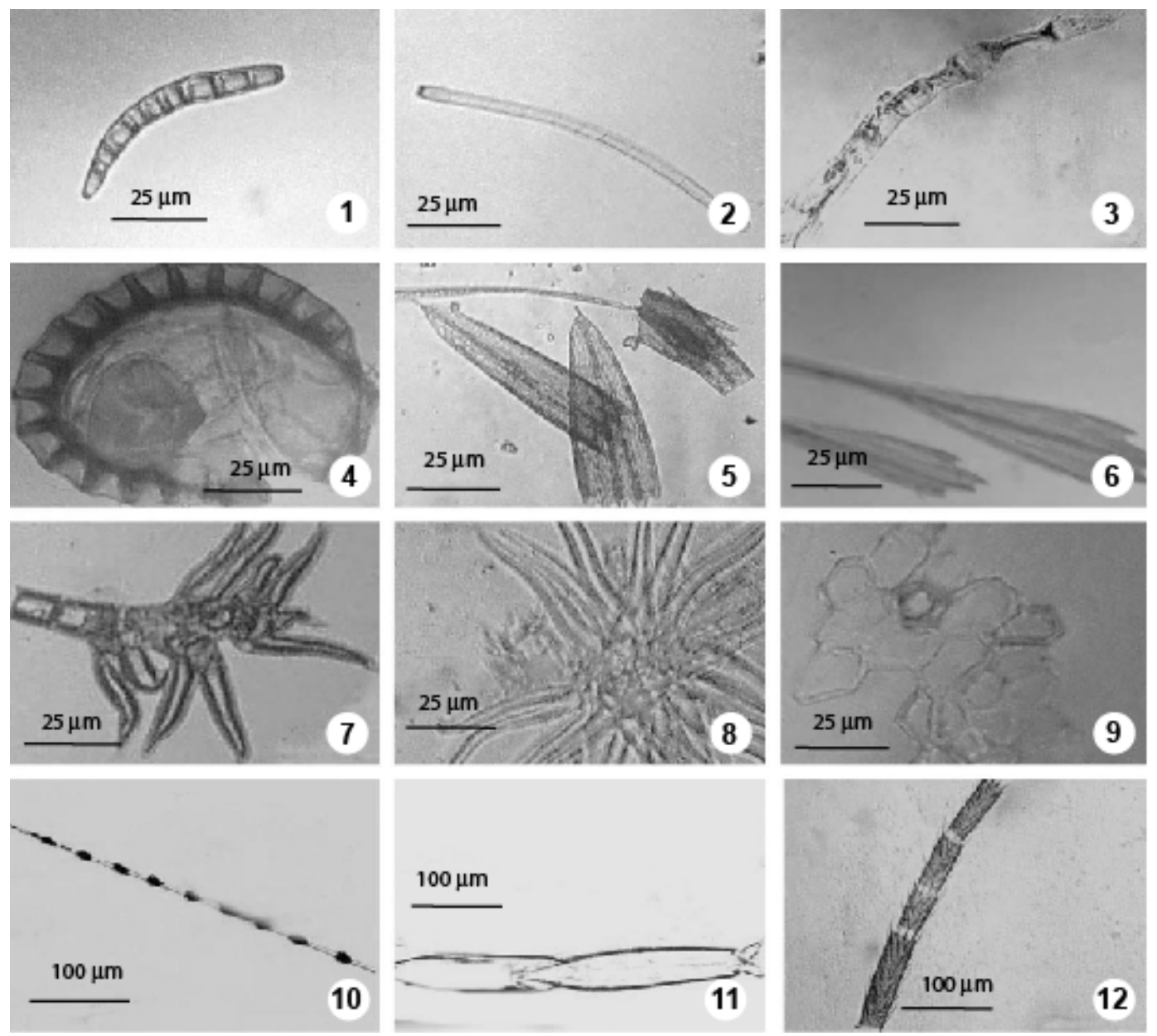

Figs 1-12. Some common trapped airborne bio-particulate objects at Chittagong University Campus. 1-2. Conidium and conidiophore. 3. Filament of a green alga. 4. Sporangium. 5-6. Bracts or glumaceous materials of either Asteraceae or Poaceae. 7-8. Dermal appendages (trichomes). 9. Epidermal tissues. 1012. Insect appendages.

All the airborne particulate objects occurred throughout the survey period except the plant tissues in the month of October (Table 1). The highest monthly incidence of airborne bioparticulate objects/fragments was observed in the month of June, followed by August, March and February. The lowest incidence occurred in the month of November, followed by October and December. When synaptic seasons are considered, then it was observed that the pre-monsoon period was the dominant season for the frequent occurrence than monsoon, and least in winter or dry season.

Dermal appendages included epidermal and non-epidermal hairs; trichomes etc. contributed a total of 333 with an average of $22.95 \%$. Munshi (1992) reported various types of trichomes from air of the Kashmir valley. But, such types of airborne plant particles are not reported in Bangladesh so far. Mandal et al. (1978) reported the potential allergenicity of various fruit parts, 
Table 1. Monthly incidence of airborne bio-particulate objects in Chittagong University Campus.

\begin{tabular}{|c|c|c|c|c|c|c|c|c|c|c|c|c|c|c|c|}
\hline \multirow{2}{*}{\multicolumn{2}{|c|}{ Particulate objects }} & \multicolumn{12}{|c|}{ Months with counts } & \multirow[t]{2}{*}{ Total } & \multirow{2}{*}{$\begin{array}{l}\text { Total } \\
\text { In } \%\end{array}$} \\
\hline & & Oct. & Nov. & Dec. & Jan. & Feb. & Mar. & Apr. & May & Jun. & Jul. & Aug. & Sep. & & \\
\hline \multicolumn{16}{|c|}{ Plant parts } \\
\hline 1 & Flower parts & 23 & 7 & 5 & 8 & 68 & 13 & 10 & 35 & 27 & 89 & 75 & 68 & 428 & 29.50 \\
\hline 2 & Dermal appendages & 8 & 3 & 7 & 20 & 28 & 83 & 55 & 30 & 44 & 14 & 23 & 18 & 333 & 22.95 \\
\hline 3 & Filamentous objects & 2 & 7 & 9 & 7 & 12 & 5 & 6 & 11 & 52 & 13 & 32 & 15 & 171 & 11.78 \\
\hline 4 & Plant tissues & - & 1 & 3 & 5 & 5 & 7 & 4 & 3 & 5 & 6 & 4 & 7 & 50 & 3.45 \\
\hline \multicolumn{16}{|c|}{ Non-plant parts } \\
\hline 5 & Insect appendages & 3 & 5 & 4 & 2 & 1 & 6 & 8 & 5 & 4 & 2 & 3 & 4 & 47 & 3.24 \\
\hline \multirow[t]{3}{*}{6} & Unidentified objects & 21 & 7 & 35 & 45 & 33 & 40 & 49 & 47 & 62 & 27 & 22 & 34 & 422 & 29.08 \\
\hline & Monthly total & 57 & 30 & 63 & 87 & 147 & 154 & 132 & 131 & 194 & 151 & 159 & 146 & 1451 & \\
\hline & Total in $\%$ & 3.93 & 2.07 & 4.34 & 6.00 & 10.13 & 10.61 & 9.10 & 9.03 & 13.37 & 10.41 & 10.96 & 10.06 & & \\
\hline
\end{tabular}

i.e. dust, fibre, placenta and seed of Luffa cylindrica in dry condition. Singh et al. (1974) worked on the allergenicity of various parts of Parethenium hysterophorus.

\section{References}

Badya KK and MK Pasha 1991. A pollen calendar for Chittagong University Campus, Chittagong (Bangladesh). Aerobiol. 7(1): 62-68.

D'Amato G, M Gentili, M Russo, G Mistrello, M Saggese, G Liccardi and P Falagiani 1994. Detection of Parietaria judaica airborne allergenic activity: comparison between immunochemical and morphological methods including clinical evaluation. Clinical Exptl. Allergy 24(6): 566-574.

Gregory PH 1961. The Microbiology of the Atmosphere, Leonard Hill and Co., London. 251 pp.

Mandal S, K Roy-Chowdhury, S Chanda, and SC Lahiri 1978. The role of Luffa cylindrica fruit as a potential allergen. Asp. Allergy Appl. Immunol. 11: 185-187.

Munshi AH 1992. Airborne pollen of Parthenium hysterosphorus in the temperate climate of Kashmir valley. Ind. J. Aerobiol. (Special vol.), pp. 61-62.

Pasha MK and MS Hossain 2009. Airborne pollen grains at Chittagong University campus, Bangladesh. Bangladesh J. Bot. 38(1): 39-46

Ramalingam A. 1971. Airspores of Mysore. Proc. Indian Acad. Sci. 74B: 227-240.

Singh AB, MPS Menon and DN Shivpuri 1974. A preliminary report on allergenicity of various parts of Parthenium hysterophorus. Asp. Allergy Appl. Immunol. 7: 47-51.

Tilak ST 1974. Aerobiology in Maharashtra. M.V.M. Patrika, 9: 125-131.

Tilak ST and OJ Chakre 1977. Indoor microbial pollution of air and its relevance to storage diseases of grains. Proc. Int. Symp. on Env. Pollution \& Toxicology, Hissar, India.

(Manuscript received on 15 October, 2011; revised on 14 November, 2011) 